\title{
FACTORS ASSOCIATED WITH ANABOLIC STEROID USE BY EXERCISE ENTHUSIASTS
}

\author{
FATORES ASSOCIADOS AO USO DE ESTEROIDES ANABOLIZANTES POR PRATICANTES DE \\ EXERCÍCIO FÍSICO
}

\section{FACTORES ASOCIADOS CON EL USO DE ESTEROIDES ANABÓLICOS POR PRACTICANTES DE EJERCICIO FÍSICO}

\begin{abstract}
Diego Correa Leite ${ }^{1}$ (Nutritionist)

Rosângela Maria Lopes de Sousa' (iD) (Nutritionist)

Antonio Luís Rodrigues Costa (ID Júnior ${ }^{2}$

(Nutritionist)

Helma Jane Ferreira Veloso ${ }^{2}$ (ID

(Nutritionist)

1. Universidade CEUMA, Nutrition Course, São Luís, MA, Brazil. 2. Universidade Federal do Maranhão (UFMA), Department of Physiological Sciences, São Luís, MA, Brazil.
\end{abstract}

\section{Correspondence:}

Helma Jane Ferreira Veloso Av. dos Portugueses, no 1966, Bacanga, São Luís, MA, Brazil. 65080-805. helmanut@gmail.com

\begin{abstract}
Introduction: Synthetic anabolic-androgenic steroids (AAS) were developed with the purpose of obtaining drugs capable of increasing protein synthesis associated with a lower degree of virilization. Its use is common among bodybuilders who aim to increase physical strength and muscle mass in the short term. However, AAS cause side effects, which restrict their therapeutic use. Objective: To identify factors associated with AAS use by exercise enthusiasts at gyms in São Luís, MA. Methods: A cross-sectional study was carried out at 17 gyms. The sample totaled 723 exercise enthusiasts, who answered a structured questionnaire with multiple choice questions related to their lifestyle and the consumption of nutritional supplements and AAS use. Logistic regression analysis was used to verify the association of socioeconomic, demographic and behavioral factors with AAS use. Results: Of the 723 exercise enthusiasts, 10.65\% reported having used AAS. Of these, $97.4 \%$ declared their awareness of some side effect caused by AAS use. Factors associated with AAS use were: being male, age between 20 and 29 years, consumption of food supplements and participation in exercise for over a year. Conclusion: The prevalence of AAS use by exercise enthusiasts at gyms in São Luís is high, and the risk factors identified enable us to target specific populations with preventive actions. Level of Evidence IIC; Cross-sectional study.
\end{abstract}

Keywords: Anabolic agents; Exercise; Fitness centers.

\section{RESUMO}

Introdução: Os esteroides anabólicos androgênicos (EAA) sintéticos foram desenvolvidos com o propósito de obter fármacos capazes de produzir aumento na síntese proteica, associados a menor grau de virilização. Seu uso é comum entre praticantes de musculação que visam aumento da força física e da massa muscular a curto prazo. Contudo, eles geram efeitos adversos, o que restringe seu uso terapêutico. Objetivo: Identificar os fatores associados ao uso de EAA por praticantes de exercício físico em academias de São Luís, MA. Métodos: Estudo transversal, realizado em 17 academias de ginástica. A amostra totalizou 723 praticantes de exercício físico, que responderam a um questionário estruturado, com questões de múltipla escolha relacionadas com seu estilo de vida e com o consumo de suplementos nutricionais e EAA. A análise de regressão logística foi empregada para verificar a associação de fatores socioeconômicos, demográficos e comportamentais ao uso de EAA. Resultados: Dos 723 praticantes de exercício físico, 10,65\% informaram ter utilizado EAA. Destes, 97,4\% afirmaram ter conhecimento de algum efeito adverso ocasionado pela utilização de EAA. Mostraram-se fatores associados ao uso de EAA: ser do sexo masculino, ter entre 20 a 29 anos, consumir suplementos alimentares e praticar exercício físico há mais de um ano. Conclusão: O consumo de EAA por praticantes de exercício físico em academias de São Luís é alto e os fatores de risco identificados permitem direcionar ações preventivas às populações específicas. Nível de Evidência IIC; Estudo transversal.

Descritores: Anabolizantes; Exercício físico; Academias de Ginástica.

\section{RESUMEN}

Introducción: Los esteroides anabólicos androgénicos (EAA) sintéticos se desarrollaron con el propósito de obtener agentes capaces de producir aumento en la síntesis de proteínas, asociados con un menor grado de virilización. Su uso es común entre los culturistas que buscan aumentar la fuerza física y la masa muscular a corto plazo. Sin embargo, tienen efectos adversos que restringen el uso terapéutico. Objetivo: Identificar los factores asociados con el uso de EAA por parte de practicantes de ejercicio físico en gimnasios de São Luis, MA. Métodos: Estudio transversal realizado en 17 gimnasios. La muestra totalizó 723 practicantes de ejercicio físico, quienes respondieron un cuestionario estructurado con preguntas de opción múltiple relacionadas con su estilo de vida y el consumo de suplementos nutricionales y EAA. El análisis de regresión logística se utilizó para verificar la asociación de factores socioeconómicos, demográficos y de comportamiento con el uso de los EAA. Resultados: De los 723 practicantes de ejercicio físico, el 10,65\% informó haber usado EAA. De estos, el 97,4\% dijo que tenían conocimiento de algún efecto adverso causado por el uso de EAA. Se mostraron los siguientes factores asociados 
con el uso de EAA: ser hombre, tener entre 20 y 29 años, consumir suplementos dietéticos y practicar ejercicio físico por más de un año.. Conclusión: El consumo de EAA por los practicantes de ejercicio físico en gimnasios de São Luis es alto y los factores de riesgo identificados pueden orientar las acciones preventivas a poblaciones específicas.

\section{Nivel de Evidencia IIC; Estudio transversal.}

\section{Descriptores: Anabolizantes; Ejercicio físico; Centros de Acondicionamiento.}

\section{INTRODUCTION}

Anabolic-androgenic steroid (AAS) hormones are prescribed for medical conditions related to low testosterone production. Due to the recognized effects on the improvement of body image, their use has been widely disseminated among fitness/exercise enthusiasts at gyms around the world. ${ }^{1}$

Users follow dosage patterns that incorporate drugs capable of increasing protein synthesis (anabolic effects) associated with a lower degree of virilization (androgenic effects). ${ }^{2}$ However, they cause undesirable side effects, which restricts their therapeutic use. ${ }^{3}$ Despite these consequences, AAS use is common among bodybuilders who aim to build up their physical strength and muscle mass in the short term. ${ }^{4,5}$

AAS are illegally marketed and consumers believe that these drugs provide more intense exercise sessions, as they delay fatigue and increase motivation and stamina. However, users do not take into consideration the fact that AAS use is associated with physical and psychological problems. ${ }^{6}$ Physical problems include a greater risk for the development of coronary heart disease, arterial hypertension and liver tumors, in addition to changes in sex hormone levels (and consequent prostatic hypertrophy and testicular and breast atrophy), voice and hair growth pattern changes, and clitoral hypertrophy in women.

According to the National Institute on Drug Abuse, ${ }^{8}$ the highest proportion of AAS misuse is among men aged between 20 and 30 years who perform resistance (weight) training. About $22 \%$ of AAS users started in their adolescence. ${ }^{9}$ Although it is increasing, steroid use among women is lower. ${ }^{10}$ The duration of regular exercise is a determining factor when making an association with AAS use. Users of these substances are assiduous frequenters of gyms and perform exercises efficiently. ${ }^{11}$

In view of the lack of data regarding the extent of AAS use in Brazil and signs that its use is increasing, which may represent a major public health problem, this study aimed to identify risk factors associated with AAS use, and to estimate the prevalence of this use by exercise enthusiasts at gyms in São Luís, Maranhão, MA.

\section{MATERIALS AND METHODS}

This is a cross-sectional study conducted between 2011 and 2012 with exercise enthusiasts at gyms in São Luís, Maranhão.

The convenience sample was based on the number of gyms registered with the Regional Council of Physical Education of Maranhão (CREF-MA), which totaled 42. These were evaluated in terms of current functioning and the types of exercise available. The selection criteria for the gyms were the number of neighborhoods in the city, their distribution by neighborhood, and the offer of resistance (weight) training by the gym. Those specific to a particular sex or age group were excluded.

Accordingly, 21 gyms met the inclusion criteria. Initially, the owners of the establishments were contacted to participate in the study. Of these, 17 agreed and four refused to take part in the study. At the gyms where consent was obtained, data were collected on the number of students enrolled, the fitness instructors available, the onsite sale of supplements, and the types of training offered.
After this phase, questionnaires were delivered directly to the gym users. They were approached randomly at the main entrances to the establishments, at different times (between $7 \mathrm{am}$ and $9 \mathrm{am}$ and between $4 \mathrm{pm}$ and $9 \mathrm{pm}$ ) and on different days of the week (Monday to Saturday). Undergraduate students enrolled in a nutrition course were trained to assist the principal investigator in data collection.

These questionnaires were standardized and validated, were self-reported and contained multiple choice questions relevant to the subject. Therefore, they covered aspects related to the lifestyle of the exercise enthusiast and the consumption of nutritional supplements and AAS use. The use of thermogenic products, protein and carbohydrate supplements, multivitamins and polyminerals, isotonic drinks, meal replacement shakes, creatine and herbal products was also investigated. Participants were able to tick more than one option in the questions. As regards the indication for supplements, the response options were nutritionist, physician, fitness instructors, friends/acquaintances, and self-prescribing.

Although 738 questionnaires were delivered, 15 were answered incompletely, with the absence of important information, and ended up representing losses. Thus, the final sample of the study consisted of 723 exercise enthusiasts who frequent gyms in São Luís, Maranhão.

Data entry was performed in duplicate, with subsequent comparison between the two entries to correct errors.

The statistical analysis included a descriptive analysis, a prevalence estimation based on the Chi-square test, used to analyze the differences between the observed and expected ratios, and a logistic regression analysis to verify the association of socioeconomic, demographic and behavioral factors with AAS use. The STATA 14.0 statistical package was used.

In the logistic regression analysis, the dependent variable was AAS use, and the explanatory variables were: length of exercise participation, occupation, education, weekly frequency at the gym, training, source of AAS recommendation, sex, and age.

The descriptive analysis was followed by the univariate analysis. For this purpose we used simple logistic regression, estimating the unadjusted relative risk and $95 \%$ confidence interval. We then performed the multivariate analysis through multiple logistic regression. The independent variables with significance below $0.20(p \leq 0.20)$ were considered candidates for the final model. However, only those with a significance level below 0.10 remained. The significance level adopted to reject the null hypothesis was 0.05 .

This study is part of the research project: "Factors associated with the consumption of nutritional supplements by exercise enthusiasts at gyms in São Luís - MA", which includes questions related to AAS use in its questionnaire. This research project fulfills the criteria of Resolution no. 196/96 of the Brazilian National Board of Health and supplementary regulations, and was approved by the Institutional Review Board of UniCEUMA under Protocol no. 316/11. All participants signed the Informed Consent Form (ICF).

\section{RESULTS}

A total of 723 exercise enthusiasts participated in the study. Male subjects (52.6\%), aged between 20 and 29 years (49.4\%), with a college/ university degree (43.1\%) and high level job occupants (51.0\%) predominated, according to Table 1. 
Regarding the characteristics of the exercise undertaken (Table 2), $46.1 \%$ of the study participants reported a length of participation greater than one year, $73.0 \%$ exercised between three and five times/week, 59.3\% spent between one and two hours exercising, 89.8\% performed anaerobic exercises and $69.6 \%$ considered their training to be moderate. Participation in exercise was linked to the consumption of nutritional supplements in $64.7 \%$ of the study sample.

With respect to AAS use (Table 3), 10.4\% of the exercise enthusiasts claimed to have used the substance in the past. Of these, $29.9 \%$ used AAS for a period between one and two months, $86.7 \%$ believed they had achieved a result while using AAS, and $41.3 \%$ took AAS on their own initiative (self-prescribing). Of the total number of exercise enthusiasts studied, $10.4 \%$ were aware of the side effects caused by AAS use, which corresponds to the percentage of those who have used AAS in the past.

Based on the simple logistic regression analysis (Table 4), being male, age between 20 and 39 years, occupying a high level position or not being a member of the economically active population, consuming

Table 1. Sociodemographic profile of exercise enthusiasts in São Luís, MA, $2012(n=723)$.

\begin{tabular}{c|c|c}
\hline Variables & $\mathbf{n}$ & $\%$ \\
\hline Sex & 380 & 52.6 \\
\hline Male & 343 & 47.4 \\
\hline Female & & \\
\hline Age & 93 & 12.9 \\
\hline$<20$ years & 357 & 49.4 \\
\hline 20 to 29 years & 181 & 25 \\
\hline 30 to 39 years & 63 & 8.7 \\
\hline 40 to 49 years & 29 & 4 \\
\hline$\geq 50$ years & & 2.8 \\
\hline Education & 20 & 30 \\
\hline Primary & 217 & 43.1 \\
\hline Secondary & 312 & 24.1 \\
\hline Higher education & 174 & 23 \\
\hline Postgraduate studies & & 51 \\
\hline Occupation & 166 & 26 \\
\hline Technician & 369 &
\end{tabular}

Table 2. Characterization of exercise participation at gyms in São Luís, MA, $2012(n=723)$.

\begin{tabular}{c|c|c}
\hline Variables & $\mathbf{n}$ & $\%$ \\
\hline Length of exercise participation & & \\
\hline$<1$ month & 118 & 16.3 \\
\hline Between 1 and 6 months & 201 & 27.8 \\
\hline Between 7 months and 1 year & 71 & 9.8 \\
\hline$>1$ year & 333 & 46.1 \\
\hline Frequency of exercises during the week & & \\
\hline$<3$ times/week & 76 & 10.5 \\
\hline Between 3 and 5 times/week & 528 & 73 \\
\hline$>5$ times/week & 119 & 16.5 \\
\hline Time spent on exercise per day & & \\
\hline$\leq 1$ hour & 212 & 29.3 \\
\hline Between 1 and 2 hours & 429 & 59.3 \\
\hline$>2$ hours & 82 & 11.4 \\
\hline Exercises performed & & \\
\hline Anaerobic ${ }^{*}$ & 649 & 89.8 \\
\hline Others & 74 & 10.2 \\
\hline Training intensity ** & & \\
\hline Light & 66 & 9.1 \\
\hline Moderate & 503 & 69.6 \\
\hline Intense & 154 & 21.3 \\
\hline Consumption of nutritional supplement & & \\
\hline Yes & 468 & 64.7 \\
\hline No & 343 & 47.4 \\
\hline$*$ Rester & &
\end{tabular}

* Resisted exercise. ${ }^{* *}$ Self-reported. food supplements, exercising for more than six months, attending the gym for more than five days a week, and spending between one and two hours per day exercising, are factors that increase the individual's chance of using AAS. The education variable did not show any statistical significance and was therefore discarded in the multivariate analysis.

In the final analysis by multiple logistic regression (Table 5), being male represents a factor associated with AAS use, since men are, with a statistically significant difference, almost three times more likely to use steroids than women. People aged 20 to 29 years are 5.77 times more likely to use AAS. Likewise, the consumption of dietary supplements and exercise participation for over a year produce an approximately two-fold increase in AAS use. The variables occupation and frequency of exercises during the week did not show statistical significance in the final model.

Table 3. Characterization of anabolic steroid use by exercise enthusiasts in São Luís, MA, $2012(n=723)$.

\begin{tabular}{c|c|c}
\hline Variables & $\mathbf{n}$ & $\%$ \\
\hline AAS Use* & & \\
\hline Yes & 75 & 10.4 \\
\hline No & 648 & 89.6 \\
\hline Length of AAS use * $^{*}$ & & \\
\hline B1 month & 21 & 27.3 \\
\hline Between 1 and 2 months & 24 & 29.9 \\
\hline Between 3 and 5 months & 9 & 11.7 \\
\hline$\geq 6$ months & 21 & 27.3 \\
\hline Results achieved with AAS use * & & 86.7 \\
\hline Yes & 65 & 13.3 \\
\hline No & 10 & 10.4 \\
\hline Knowledge of the side effects of AAS use & & 89.6 \\
\hline Yes & 75 & \\
\hline No & 648 & 41.3 \\
\hline Responsible for indicating AAS use* & & 38.7 \\
\hline Self-prescribing & 31 & 10.7 \\
\hline Friend & 29 & 9.3 \\
\hline Coach & 7 & \\
\hline Others & & \\
\hline
\end{tabular}

AAS: anabolic-androgenic steroids; ${ }^{*} \mathrm{n}$ below 723.

Table 4. Univariate analysis by simple logistic regression of the factors associated with anabolic steroid use by exercise enthusiasts in São Luís, MA, 2012 ( $n=723$ ).

\begin{tabular}{|c|c|c|c|}
\hline Variables & OR & $(95 \%) \mathrm{Cl}$ & p-value* \\
\hline \multicolumn{4}{|l|}{ Sex } \\
\hline Male & 3.07 & $1.79-5.27$ & 0.000 \\
\hline \multicolumn{4}{|l|}{ Age } \\
\hline 20 to 29 years & 3.97 & $1.40-11.25$ & 0.010 \\
\hline 30 to 39 years & 2.16 & $0.70-6.65$ & 0.181 \\
\hline 40 to 49 years & 1.11 & $0.24-5.15$ & 0.892 \\
\hline \multicolumn{4}{|l|}{ Education } \\
\hline Higher education & 1.18 & $0.69-2.03$ & 0.542 \\
\hline Postgraduate studies & 0.65 & $0.32-1.32$ & 0.231 \\
\hline \multicolumn{4}{|l|}{ Occupation } \\
\hline High level & 0.61 & $0.35-1.05$ & 0.076 \\
\hline Not part of the economically active population & 0.52 & $0.27-1.02$ & 0.058 \\
\hline \multicolumn{4}{|l|}{ Consumption of supplements } \\
\hline Yes & 2.44 & $1.36-4.39$ & 0.03 \\
\hline \multicolumn{4}{|l|}{ Length of exercise participation } \\
\hline Between 1 and 6 months & 0.84 & $0.38-1.88$ & 0.673 \\
\hline Between 7 months and 1 year & 0.28 & $0.06-1 ; 31$ & 0.106 \\
\hline$>1$ year & 1.63 & $0.82-3.27$ & 0.162 \\
\hline \multicolumn{4}{|l|}{ Frequency of exercises during the week } \\
\hline Between 3 and 5 times/week & 1.05 & $0.46-2.42$ & 0.901 \\
\hline$>5$ times/week & 1.87 & $0.75-4.70$ & 0.181 \\
\hline \multicolumn{4}{|l|}{ Time spent on exercise per day } \\
\hline Between 1 and 2 hours & 0.69 & $0.41-1.15$ & 0.155 \\
\hline$>2$ hours & 1.06 & $0.50-2.25$ & 0.876 \\
\hline
\end{tabular}


Table 5. Final analysis by multiple logistic regression of factors associated with the use of anabolic steroids by exercise enthusiasts in São Luís, MA, $2012(n=723)$.

\begin{tabular}{c|c|c|c}
\hline Variables & OR & (95\%) $\mathbf{C l}$ & p-value* \\
\hline Sex & & & \\
\hline Male & 2.94 & $1.68-5.14$ & 0.000 \\
\hline Age & & & \\
\hline 20 to 29 years & 5.77 & $2.51-13.30$ & 0.000 \\
\hline 30 to 39 years & 2.78 & $1.08-7.17$ & 0.034 \\
\hline Occupation & & & \\
\hline High level & 0.67 & $0.40-1.11$ & 0.121 \\
\hline Consumption of supplements & & & \\
\hline Yes & 2.08 & $1.13-3.83$ & 0.018 \\
\hline Frequency of exercises during the week & & & \\
\hline$>5$ times/week & 1.75 & $0.96-3.19$ & 0.067 \\
\hline Length of exercise participation & \multicolumn{3}{|l}{} \\
\hline$>1$ year & 1.90 & $1.13-3.19$ & 0.015 \\
\hline *p-value considered significant: p<0.05. ${ }^{*}$ The table shows only the variables with p-value $<<0.20$ in one of the categories.
\end{tabular}

\section{DISCUSSION}

The profile of exercise enthusiasts at gyms in São Luís, Maranhão, is made up of individuals of both sexes, mostly aged between 20 and 29 years, with a high level of education and occupying high level jobs.

A considerable percentage of exercise enthusiasts reported having used AAS in the past. However, the prevalence found (10.4\%) may have been underestimated, especially since it is an illegal practice. This fact tends to inhibit the responses of participants in studies of this nature, which is a limitation of this study but does not invalidate its results.

A systematic review of the literature found the prevalence of AAS use by exercise enthusiasts in Brazil ranging from 2.1\% to 31.6\%, depending on the sample characteristics and the region analyzed. ${ }^{12}$

In a municipality of the state of Bahia, for example, it was noted that $46 \%$ of the participants reported having made use of AAS in the past, and that the substance most frequently used was testosterone (43.5\% of the total), either alone or in combination with other anabolic drugs. ${ }^{13}$

There was a greater prevalence of AAS users among men, and this association had a $3 x$ higher odds ratio than women, corroborating the findings of other studies. ${ }^{14-16}$ This difference can be explained by the characteristics of virilization, which are considered undesirable by females. Conversely, for men, having voluminous muscles constitutes an aesthetic standard that is increasingly coveted and widespread.
The largest proportion of AAS users in this study consisted of young men (20 to 29 years old) with an odds ratio almost six times higher than the other age groups. This profile was also identified in a survey conducted in the city of Curitiba. ${ }^{14}$

In this particular study, occupation and education were not associated with AAS use. However, it is also necessary to discuss different nomenclatures such as the term "hormone replacement", which may not have been considered by some study participants. Based on a formal discussion of forced hormone deficiency, some professionals prescribe testosterone and its derivatives considering the need for replacement. ${ }^{17}$

The consumption of dietary supplements was associated with AAS use, causing a twofold increase in these odds. The use of supplements and anabolic steroids is the most modish aspect of sports nutrition. Athletes or exercise enthusiasts believe in a greater competitive advantage with the use of these products. AAS users consume significantly more nutritional supplements, vitamins and minerals than non-users. The goal that prompts users to take supplements is the same that encourages the use of AAS: increased strength and muscle mass. ${ }^{18}$

In this research project, individuals who have been exercising for more than a year are twice as likely to use AAS compared to those who have been exercising for less time. The level of muscle training is higher among AAS users, both with regard to recreational sportspeople and former bodybuilders and athletes. ${ }^{19}$

\section{CONCLUSIONS}

The indiscriminate use of AAS was found to be prevalent in the sample studied and was associated with being male, age between 20 and 29 years, the consumption of nutritional supplements, and length of exercise participation over one year. These results draw our attention to the need for preventive and informative actions with the population of young adults, and for more studies that help us draw the profile of AAS users. In this way, these protective measures can be targeted and prove effective.

\section{ACKNOWLEDGMENTS}

This research project received financial support from the Fundação de Amparo à Pesquisa e ao Desenvolvimento Científico e Tecnológico do Maranhão [Foundation for the Support of Research and Scientific and Technological Development of Maranhão] (FAPEMA - BIC - 00661/2011).

All authors declare no potential conflict of interest related to this article

AUTHORS' CONTRIBUTIONS: Each author made significant individual contributions to this manuscript. DCL and RMLS: data analysis and interpretation and review; ALRCJ: data analysis and interpretation and writing; HJFV (0000-0003-2456-6538):* review and conception of the entire research project. All authors reviewed and approved the final version of the manuscript.

\section{REFERENCES}

1. Mullen C, Whalley BJ, Schifano F, Baker JS. Anabolic androgenic steroid abuse in the United Kingdom: An update. Br J Pharmacol. 2020;177(10):2180-98.

2. Pope Jr HG, Wood RI, Rogol A, Nyberg F, Bowers L, Bhasin S. Adverse health consequences of performance-enhancing drugs: an Endocrine Society scientific statement. Endocr Rev. 2014;35(3):341-75.

3. Pope Jr HG, Khalsa JH, Bhasin S. Body image disorders and abuse of anabolic-androgenic steroids among men. JAMA. 2017;317(1):23-4.

4. Sagoe D, Andreassen CS, Pallesen S. The aetiology and trajectory of anabolic-androgenic steroid use initiation: a systematic review and synthesis of qualitative research. Subst Abuse Treat Prev Policy. 2014;9:27.

5. Kanayama G, Hudson Jl, DeLuca J, Isaacs S, Baggish A, Weiner R, et al. Prolonged hypogonadism in males following withdrawal from anabolic-androgenic steroids: an under-recognized problem. Addiction. 2015;110(5):823-31.

6. Rasmussen JJ, Schou M, Madsen PL, Selmer C, Johansen ML, Ulriksen PS, et al. Cardiac systolic dysfunction in past illicit users of anabolic androgenic steroids. Am Heart J. 2018;203:49-56.

7. Baggish AL, Weiner RB, Kanayama G, Hudson Jl, Lu MT, Hoffmann U, et al. Cardiovascular toxicity of illicit anabolic-androgenic steroid use. Circulation. 2017;135(21):1991-2002.

8. National Institute on Drug Abuse/NIDA. Anabolic steroids. [internet]. 2018. [access on 2020 Apr 30]. Available at: https://www.drugabuse.gov/publications/drugfacts/anabolic-steroids.

9. Kanayama G, Pope Jr HG. History and epidemiology of anabolic androgens in athletes and nonathletes. Mol Cell Endocrinol. 2018;464:4-13.

10. Pope Jr HG, Kanayama G, Athey A, Ryan E, Hudson Jl, Baggish A. The lifetime prevalence of anabolic-androgenic steroid use and dependence in Americans: current best estimates. Am J Addict Am Acad Psychiatr Alcohol Addict. 2014;23(4):371-7.

11. Nogueira FR, Brito AF, Vieira TI, Oliveira CV, Gouveia RL. Prevalência de uso de recursos ergogênicos em praticantes de musculação na cidade de João Pessoa, Paraíba. Rev Bras Cien Esporte. 2015;37(1):56-64

12. Abrahin OS, Sousa EC, Santos AM. Prevalence of the use of anabolic-androgenic steroids in Brazil: a systematic review. Subst Use Misuse. 2014;49(9):1156-62.

13. Oliveira LL, Cavalcante NJ. Fatores sociodemográficos, perfil dos usuários e motivação para o uso de esteroides anabolizantes entre jovens adultos. Rev Bras Cien Esporte. 2018:40(3):309-17.

14. Pereira E, Moyses SJ, Ignácio SA, Mendes DK, Silva DS, Carneiro E, et al. Prevalence and profile of users and non-users of anabolic steroids among resistance training practitioners. BMC Public Health. 2019;19(1):1650.

15. Sousa S, Rodrigues WR, Silva RA, Zanuto EC. Profile of users anabolic steroids of city Presidente Prudente-SP. Rev Bras Nutri Esportiva. 2017;11:383-9.

16. Silva GG, Brito AF, Nogueira FR, Rodrigues Júnior JF, Ribeiro SL, Oliveira CV, et al. Prevalence of anabolicandrogenic steroids on bodybuilders of Teresina-PI. Rev Port Cien Desporto. 2017;17:115-24.

17. Baptista JG, Brandão ER. Training practices at the gym: different social uses of dietary supplements and anabolic steroids. Cad Saude Publica. 2018;34(2):e00190917.

18. Silva AC. Corpos no limite: Suplementos alimentares e anabolizantes em academias de ginástica. Jundiaí: Paço Editorial, 2017. 200p.

19. Anawalt BD. Diagnosis and Management of Anabolic Androgenic Steroid Use. J Clin Endocrinol Metab. 2019;104(7):2490-500 